\title{
SEXUALLY TRANSMITTED DISEASES: KNOWLEDGE AND SEXUAL BEHAVIOR OF ADOLESCENTS
}

\author{
Niviane Genz'1, Sonia Maria Könzgen Meincke², Maria Laura Vidal Carret³, Ana Cândida Lopes Corrêa ${ }^{4}$, Camila \\ Neumaier Alves ${ }^{5}$
}

${ }^{1}$ M.Sc. in Sciences. Nurse, Hospital Escola da Universidade Federal de Pelotas (UFPel). Pelotas, Rio Grande do Sul, Brazil. E-mail: niviane28@yahoo.com.br

${ }^{2}$ Ph.D. in Nursing. Professor, Department of Nursing, Faculty of Nursing and Obstetrics of the UFPel. Pelotas, Rio Grande do Sul, Brazil. E-mail: meinckesmk@gmail.com

${ }^{3}$ Ph.D. in Epidemiology. Professor of Medicine, UFPel. Pelotas, Rio Grande do Sul, Brazil. E-mail: mvcarret@hotmail.com

${ }^{4}$ Doctoral student, Postgraduate Program in Nursing, UFPel. Pelotas, Rio Grande do Sul, Brazil. E-mail: analopescorrea@ hotmail.com

${ }^{5}$ Doctoral student, Postgraduate Program in Nursing, UFPel. Professor, Centro Universitário Ritter do Reis. Porto Alegre, Rio Grande do Sul, Brazil. E-mail: camilaenfer@gmail.com

\begin{abstract}
Objective: to evaluate the sexual knowledge and behavior of adolescents about Sexually Transmitted Diseases.

Method: a descriptive, observational and quantitative study with a convenience sample of 532 adolescents aged between 10 and 19 years old. An individual questionnaire on sexually transmitted diseases was applied. The STATA 11.1 program was used for data analysis.

Results: $89.2 \%$ of the teenage girls and $90.3 \%$ of the teenage boys were able to properly define the concept of a STD. Condom use is the most efficient method for STD prevention for $98.5 \%$ of the girls and $98.9 \%$ of the boys. However, $37.1 \%$ of the girls and $30.5 \%$ of the boys mentioned the use of contraceptives as a preventive method for sexually transmitted diseases.

Conclusion: it is important to carry out educational actions together with schools on topics such as sexuality and reproductive health.

DESCRIPTORS: Adolescent. Sexually transmitted diseases. Sexual and reproductive rights. Sex education. Nursing.

\section{DOENÇAS SEXUALMENTE TRANSMISSÍVEIS: CONHECIMENTO E COMPORTAMENTO SEXUAL DE ADOLESCENTES}

\section{RESUMO}

Objetivo: avaliar o conhecimento e comportamento sexual de adolescentes sobre doenças sexualmente transmissíveis.

Método: estudo descritivo, observacional, de caráter quantitativo, com amostra por conveniência de 532 adolescentes entre 10 e 19 anos. Aplicou-se um questionário individual sobre doenças sexualmente transmissíveis. Para a análise dos dados utilizou-se o programa STATA 11.1.

Resultados: 89,2\% das meninas e 90,3\% dos meninos souberam definir adequadamente o conceito de doenças sexualmente transmissíveis; para $98,5 \%$ das meninas e $98,9 \%$ dos meninos o uso de preservativo é o método mais eficaz para prevenção dessas doenças. Entretanto, 37,1\% das meninas e 30,5\% dos meninos referiram o uso de anticoncepcional como método preventivo para doenças sexualmente transmissíveis.

Conclusão: torna-se salutar a realização de ações educativas junto à escola sobre temas como sexualidade e saúde reprodutiva.

DESCRITORES: Adolescente. Doenças sexualmente transmissíveis. Direitos sexuais e reprodutivos. Educação sexual. Enfermagem. 


\section{ENFERMEDADES DE TRANSMISIÓN SEXUAL: EL CONOCIMIENTO Y COMPORTAMIENTO SEXUAL DE LOS ADOLESCENTES}

\section{RESUMEN}

Objetivo: evaluar el conocimiento y comportamiento sexual de los adolescentes acerca de Enfermedades de Transmisión Sexual.

Metodo: estudio descriptivo, observacional, cuantitativo, con muestra de conveniencia con 532 adolescentes entre 10 y 19 años. El cuestionario fue administrado sobre ETS. Para el análisis de los datos se utilizó el programa STATA11.1. El proyecto fue aprobado por el.

Resultados: 89,2\% de las chicas y el 90,3\% de los chicos supieron definir adecuadamente el concepto de ETS; $98,5 \%$ de las chicas y $98,9 \%$ de los chicos el uso del preservativo es el método más eficaz para la prevención. Sin embargo, el 37,1\% de las chicas y el 30,5\% de los chicos reportaron el uso de anticonceptivos como método preventivo.

Conclusion: es saludable la realización de acciones educativas junto a la escuela sobre temas tales como la sexualidad y la salud reproductiva. DESCRIPTORES: Adolescente. Enfermedades de transmisión sexual. Derechos sexuales y reproductivos. Educación sexual. Enfermería.

\section{INTRODUCTION}

Adolescence is a period marked by biopsychosocial changes in which one's peers gain importance and sexuality is more exacerbated. Adolescents may experience unsafe sexual practices due to lack of information, lack of communication with relatives due to taboos or fear of sharing their sexual experiences with the family. ${ }^{1}$

The transition from childhood to adulthood is characterized by a period of distancing from behaviors and privileges typical of childhood. It leads to psychological maturation where the personality is structured in searching for an identity and acquisition of adult characteristics, in addition to economic independence and moving out of their parents' house. These changes often generate crises, conflicts and contradictions, but they are essentially positive for biopsychosocial maturation. It is considered a moment of great vulnerability due to the new aspirations that arise in this period. ${ }^{2-3}$

In this context, we can highlight the issue of Sexually Transmitted Diseases (STDs) and the importance of discussing this with groups of adolescents. According to a study ${ }^{4}$ that sought results regarding teenagers' knowledge of STDs, it was revealed that on average they knew of five to six sexually transmitted diseases, with AIDS being the most cited $(92.2 \%)$. However, the same study showed no knowledge regarding syphilis (35.6\%), genital herpes $(33.3 \%)$, gonorrhea $(30.0 \%)$ and HPV $(27.2 \%)$.

Another study ${ }^{5}$ identified that $100 \%$ of adolescents investigated were aware that STD transmission occurred through sexual intercourse. Moreover, $63.0 \%$ of these adolescents cited the use of condoms as the most appropriate method for prevention, although the use of the contraceptive pill $(28.3 \%)$ and the morning-after pill $(5.6 \%)$ were cited as (prevention) methods.
One study ${ }^{6}$ reports that having multiple partners may increase the risk of acquiring STDs. However, despite participants of a different study ${ }^{7}$ being aware about this subject, they presented risky behaviors evidenced by the early onset of sexual activities, multiplicity of partners and use of alcoholic beverages.

We believe that educational actions can play an important role throughout adolescence, since they provide information and the opportunity to exchange experiences about healthy sexual activity. A corroborating study conducted over a decade ago ${ }^{8}$ reported that sex education programs performed by empathic educators with specific training in the subject can increase knowledge about sexuality, as well as promote safer sex practices among adolescents. It is worth emphasizing that the Ministry of Health recommends that healthy sexual and reproductive education in addition to STD prevention education are offered to students in the final years of elementary and middle school. ${ }^{9}$

In view of the above, we propose the following research question: what is the sexual knowledge and sexual behavior of adolescents about sexually transmitted diseases? Thus, we aimed to evaluate the sexual knowledge and sexual behavior of adolescents about sexually transmitted diseases.

\section{METHOD}

This is a descriptive study using a quantitative and observational approach with convenience sampling. The study population was comprised of 1,011 students from a municipal school in the south of Rio Grande do Sul, Brazil. Data were collected in July 2014. Inclusion criteria were: being enrolled and attending the $7^{\text {th }}$ and $8^{\text {th }}$ grades of middle school or in high school; and being between 10 and 19 years old.

The applied instrument was a self-administered, anonymous, pre-coded questionnaire based 
on the questionnaire from the research "Knowledge, practice and behaviors" of the Ministry of Health $^{10}$, divided into three blocks represented by sociodemographic data, behavioral data and knowledge about STDs. The questionnaire was applied in the classroom with prior authorization from parents, the school's directors and teachers. After reviewing and coding the data, data were double-entered into the EXCEL® program with consistency checking, and then transferred to the STATA® 11.1 program for analysis.

As this study was based on the questionnaire by the Ministry of Health ${ }^{10}$, the variables were distributed according to the blocks indicated in this publication. Sociodemographic variables studied were age, gender, schooling and income. The income variable considered the national minimum wage, which at the time of the study was $\mathrm{R} \$ 724.00$.

For the behavioral data, variables of age at first sexual intercourse, condom use in the first and last encounters, number of sexual partners in the last year and being responsible for the prevention of STDs were considered. In order to evaluate knowledge about STDs, questions from the Knowledge block were used, including the definition of STDs, diseases that are considered sexually transmissible, those that have a cure, means of infection, prevention methods and sources of information on STDs. The variables age, gender, number of partners in the last year and age at first sexual intercourse were described by mean and standard deviation. Categorical variables were described by absolute and relative frequencies.

The outcome Knowledge was considered appropriate for those who defined STD as "a disease transmitted through sexual intercourse (vaginal, oral, anal) with people infected by STDs." The most well-known STDs considered were HIV/AIDS, syphilis, HTLV - Human T-Lymphotropic Virus, HPV - Human Papilloma Virus, herpes, gonorrhea, PID - Pelvic Inflammatory Disease, trichomoniasis, chlamydia, donovanosis, venereal lymphogranuloma, chancroid, and viral hepatitis.

Regarding a question on which STDs are curable, responses considered acceptable were syphilis, HPV, gonorrhea, PID, trichomoniasis, chlamydia, donovanosis, venereal lymphogranuloma, chancroid and viral hepatitis. Regarding transmission forms, the responses considered were vaginal intercourse, oral intercourse, anal intercourse, use of shared syringes, piercing, tattooing, manicure, breastfeeding and blood transfusion. As for STD prevention methods, the expected response was the use of condoms.

Pearson's chi-square test or Fisher's exact test were used to evaluate the association between categorical variables. Statistically significant values were those that presented a value of $p<0.05$, thus constituting a level of significance of $95 \%$.

The study development was approved by the Research Ethics Committee under Opinion number 702.277, and met the ethical precepts of research involving humans according to Resolution 466/12. Parents and/or guardians were required to sign the Free and Informed Consent Form (ICF) for the participants in the case of minors (under 18), and students were required to sign the Assignment Term. In the case of participants of legal age (over 18), only the students were asked to sign the ICF.

\section{RESULTS}

Among the eligible population, 945 were attending school at the time of the survey. A total of 610 students answered the questionnaire, however a total of 532 students were included in the study following the pre-established inclusion criteria, as 78 students were above 19 years of age. Among those who did not respond to the questionnaire, 25 refused, 146 were not in the classroom at the time of applying the survey questionnaire, and the remaining 164 students did not submit the ICFs duly signed by their parents.

There was a predominance of females with $65.2 \%$. The mean age was $15.2 \pm 1.96$ years. Regarding skin color, there was a predominance of Caucasian ethnicity with $70.9 \%$. A total of $97.1 \%$ reported being single. Of the 532 participating adolescents, $51.9 \%$ were enrolled in the $7^{\text {th }}$ and $8^{\text {th }}$ grades of middle school and $48.1 \%$ were in high school. Out of the total sample of adolescents, $16.1 \%$ worked; regarding family income distribution, $21.1 \%$ had income of up to 1 minimum wage; $55.2 \%$ between 1 and $3 ; 16.3 \%$ between 3 and 5 ; and $7.4 \%$ reported family income greater than 5 minimum wages.

Table 1 shows that $36.6 \%$ of the girls and $43.3 \%$ of the boys among the participants had already had sex. The first sexual intercourse occurred for girls at an average of 14.8 years of age \pm 1.5 years, and the median was 15 years; and average sexual initiation for the boys was at 14.4 years \pm 1.5 years, and the median was 15 years. Of the total, four had no partner in the previous year; 162 had one to five and 18 had six partners or more in the last year, with an 
average of $2.5 \pm 3.7$ partners in the previous year. Condom use during the first intercourse was mentioned by $72.1 \%$ of the girls and $74.0 \%$ of the boys, whereas $55.4 \%$ of the girls and $76.3 \%$ of the boys had continued to use one in the last sexual intercourse.
Regarding responsibility for preventing of STD, $96.6 \%$ believed that it was the responsibility of both men and women; $2.0 \%$ reported it being the responsibility of man; $0.8 \%$ thought it was the responsibility of women; and $0.6 \%$ did not respond.

Table 1 - Behavioral variables related to age at the time of their first sexual intercourse, use of condoms in the first and last intercourse, and responsibility for STD prevention. Pelotas-RS, Brazil, 2014

\begin{tabular}{|c|c|c|c|c|c|}
\hline \multirow{3}{*}{ Variable } & \multicolumn{5}{|c|}{ Gender } \\
\hline & \multicolumn{2}{|c|}{ Female } & \multicolumn{2}{|c|}{ Male } & \multirow[b]{2}{*}{$\mathbf{P}^{*}$} \\
\hline & $\mathbf{n}$ & $\%$ & $\mathbf{n}$ & $\%$ & \\
\hline Had sexual intercourse $(n=519)$ & & & & & 0.1 \\
\hline Yes & 124 & 36.6 & 78 & 43.3 & \\
\hline No & 215 & 63.4 & 102 & 56.7 & \\
\hline Age at first sexual intercourse $(n=187)$ & & & & & 0.2 \\
\hline Up to 13 years of age & 17 & 14.8 & 17 & 23.6 & \\
\hline 14 to 16 years of age & 84 & 73.0 & 51 & 70.8 & \\
\hline 17 to 18 years of age & 14 & 12.2 & 4 & 5.6 & \\
\hline Number of partners in the previous year $(n=184)$ & & & & & 0.5 \\
\hline None & 2 & 1.7 & 2 & 3.1 & \\
\hline 1 to 5 partners & 113 & 94.2 & 49 & 76.6 & \\
\hline 6 or more partners & 5 & 4.1 & 13 & 20.3 & \\
\hline Used a condom in first sexual intercourse $(n=199)$ & & & & & 0.9 \\
\hline Yes & 88 & 72.1 & 57 & 74.0 & \\
\hline No & 32 & 26.2 & 19 & 24.7 & \\
\hline Not sure/Did not respond & 2 & 1.7 & 1 & 1.3 & \\
\hline Used a condom in the last sexual intercourse $(n=201)$ & & & & & 0.01 \\
\hline Yes & 67 & 55.4 & 61 & 76.3 & \\
\hline No & 51 & 42.1 & 17 & 21.2 & \\
\hline The person responsible for STD prevention $(n=520)$ & & & & & 0.9 \\
\hline Women & 2 & 0.6 & 2 & 1.1 & \\
\hline Men & 6 & 1.8 & 4 & 2.2 & \\
\hline Both & 329 & 97.0 & 174 & 96.1 & \\
\hline Not sure & 2 & 0.6 & 1 & 0.6 & \\
\hline
\end{tabular}

${ }^{*}$ Chi-square test.

Table 2 identifies that $89.2 \%$ of the girls and $90.3 \%$ of the boys adequately defined STD as a sexually transmitted disease (vaginal, anal or oral) with a partner infected by the disease; however, there was no statistically significant difference between the knowledge of teenage girls and boys $(\mathrm{P}=0.7)$.

A total of $2.9 \%$ of the girls and $4.6 \%$ of the boys considered the definition of a STD as a disease transmitted by the contact of hands, kisses, hugs, sharing of personal objects and shared use of toilets with people infected by a STD; $7.6 \%$ of girls and $5.1 \%$ of boys reported that both statements were correct definitions for STDs; and only $0.3 \%$ of girls were not sure how to respond.

When questioned about which STDs they knew, $78.0 \%$ of girls and $89.3 \%$ of boys had adequate knowledge regarding which diseases are considered STDs, and the boys knew more STDs than the girls $(\mathrm{P}=0.002)$. 
Table 2 - Variables grouped by responses considered appropriate regarding the adolescents' knowledge about STDs. Pelotas-RS, Brazil, 2014

\begin{tabular}{|c|c|c|c|c|c|}
\hline \multirow{3}{*}{ Variable } & \multicolumn{5}{|c|}{ Gender } \\
\hline & \multicolumn{2}{|c|}{ Female } & \multicolumn{2}{|c|}{ Male } & \multirow[b]{2}{*}{$\mathbf{P}^{*}$} \\
\hline & $\mathbf{n}$ & $\%$ & $\mathbf{N}$ & $\%$ & \\
\hline Can define STD $(\mathrm{n}=516)$ & & & & & 0.7 \\
\hline No & 37 & 10.8 & 17 & 9.7 & \\
\hline Yes & 304 & 89.2 & 158 & 90.3 & \\
\hline Know STDs $(n=522)$ & & & & & 0.002 \\
\hline No & 75 & 22.0 & 19 & 10.7 & \\
\hline Yes & 266 & 78.0 & 158 & 89.3 & \\
\hline Can identify diseases that are curable $(n=469)$ & & & & & 0.02 \\
\hline No & 222 & 73.7 & 95 & 62.9 & \\
\hline Yes & 79 & 26.3 & 56 & 37.1 & \\
\hline Recognizes forms of infection/transmission $(n=511)$ & & & & & 0.15 \\
\hline No & 205 & 61.9 & 95 & 55.2 & \\
\hline Yes & 126 & 38.1 & 77 & 44.8 & \\
\hline Understands forms of prevention $(n=518)$ & & & & & 0.03 \\
\hline No & 200 & 58.6 & 85 & 48.6 & \\
\hline Yes & 141 & 41.4 & 90 & 51.4 & \\
\hline
\end{tabular}

* Chi-square test.

Table 3 shows the stratification by gender and school year regarding STDs that adolescents knew and believed to be curable. The most mentioned diseases by the participants were Acquired Immunodeficiency Syndrome (AIDS), herpes; gonorrhea; Human Papilloma Virus (HPV); syphilis and viral hepatitis. A statistically significant difference was observed for education level in both genders regarding the knowledge of syphilis $(\mathrm{P}=0.001)$; only for girls $(\mathrm{P}=0.04)$ regarding HPV; only for boys $(\mathrm{P}=0.006)$ regarding gonorrhea; and only for girls $(\mathrm{P}<0.001)$ regarding viral hepatitis. The existence of chancroid was reported by a small number of participants, with a significant difference for both genders $(\mathrm{P}=0.02$ for girls and $\mathrm{P}=0.03$ for boys).

Table 3 - Sexually transmitted diseases that adolescents reported knowing and believed to be curable, stratified by gender and school year. Pelotas-RS, Brazil, 2014

\begin{tabular}{|c|c|c|c|c|c|c|c|c|c|c|}
\hline \multirow{3}{*}{ Variable } & \multicolumn{7}{|c|}{ Girls } & \multirow{2}{*}{\multicolumn{3}{|c|}{$\begin{array}{l}\text { Boys } \\
\text { High school }\end{array}$}} \\
\hline & \multicolumn{2}{|c|}{$\begin{array}{c}7^{\text {th }} \text { and } 8^{\text {th }} \\
\text { grades }\end{array}$} & \multicolumn{3}{|c|}{ High school } & \multicolumn{2}{|c|}{$\begin{array}{c}7^{\text {th }} \text { and } 8^{\text {th }} \\
\text { grades }\end{array}$} & & & \\
\hline & $\mathbf{n}$ & $\%$ \% & $\mathbf{n}$ & $\%$ \% & $\mathbf{P}^{\dagger}$ & $\mathbf{n}$ & $\%$ \% & $\mathbf{n}$ & $\%$ * & $\mathbf{P}^{\dagger}$ \\
\hline \multicolumn{11}{|c|}{ Known STDs $(\mathrm{n}=522)$} \\
\hline Aids & 159 & 98.2 & 177 & 97.8 & $0.8^{\ddagger}$ & 104 & 96.3 & 69 & 97.2 & $0.9^{\ddagger}$ \\
\hline Syphilis & 58 & 35.8 & 108 & 59.7 & $<0.001$ & 20 & 18.5 & 42 & 59.2 & $<0.001$ \\
\hline HTLV & 15 & 9.3 & 8 & 4.4 & $0.1^{\ddagger}$ & 11 & 10.2 & 4 & 5.6 & $0.4^{\ddagger}$ \\
\hline HPV & 112 & 69.1 & 106 & 58.6 & 0.04 & 39 & 36.1 & 29 & 40.9 & 0.5 \\
\hline Herpes & 107 & 66.1 & 135 & 74.6 & 0.1 & 52 & 48.2 & 42 & 59.2 & 0.2 \\
\hline Gonorrhea & 86 & 53.1 & 113 & 62.4 & 0.08 & 46 & 42.6 & 45 & 63.4 & 0.006 \\
\hline
\end{tabular}




\begin{tabular}{|c|c|c|c|c|c|c|c|c|c|c|}
\hline \multirow{3}{*}{ Variable } & \multicolumn{7}{|c|}{ Girls } & \multirow{2}{*}{\multicolumn{3}{|c|}{$\begin{array}{l}\text { Boys } \\
\text { High school }\end{array}$}} \\
\hline & \multicolumn{2}{|c|}{$\begin{array}{c}7^{\text {th }} \text { and } 8^{\text {th }} \\
\text { grades }\end{array}$} & \multicolumn{3}{|c|}{ High school } & \multicolumn{2}{|c|}{$\begin{array}{c}7^{\text {th }} \text { and } 8^{\text {th }} \\
\text { grades }\end{array}$} & & & \\
\hline & $\mathbf{n}$ & $\% *$ & $\mathbf{n}$ & $\% *$ & $\mathbf{P}^{\dagger}$ & $\mathbf{n}$ & $\% *$ & $\mathbf{n}$ & $\% *$ & $\mathbf{P}^{\dagger}$ \\
\hline PID & 14 & 8.6 & 19 & 10.5 & $0.6^{\ddagger}$ & 11 & 10.2 & 7 & 9.9 & $0.9^{\ddagger}$ \\
\hline Trichomoniasis & 7 & 4.3 & 10 & 5.5 & $0.6^{\ddagger}$ & 3 & 2.8 & 4 & 5.6 & $0.4^{\ddagger}$ \\
\hline Chlamydia & 10 & 6.2 & 13 & 7.2 & $0.8^{\ddagger}$ & 5 & 4.6 & 1 & 1.4 & $0.4^{\ddagger}$ \\
\hline Donovanosis & 3 & 1.8 & 2 & 1.1 & $0.7^{\ddagger}$ & 3 & 2.8 & 0 & 0.0 & 0.3 \\
\hline Lymphogranuloma Venereal & 3 & 1.8 & 7 & 3.9 & $0.3^{\ddagger}$ & 4 & 3.7 & 1 & 1.4 & $0.6^{\ddagger}$ \\
\hline Mycoplasma & 9 & 5.6 & 15 & 8.3 & 0.4 & 4 & 3.7 & 2 & 2.8 & $0.9^{\ddagger}$ \\
\hline Urethroma & 6 & 3.7 & 7 & 3.9 & $0.9^{\ddagger}$ & 4 & 3.7 & 4 & 5.6 & $0.7^{\ddagger}$ \\
\hline Chancroid & 11 & 6.8 & 26 & 14.4 & 0.02 & 10 & 9.3 & 15 & 21.1 & 0.03 \\
\hline Viral hepatitis & 39 & 24.1 & 81 & 44.8 & $<0.001$ & 21 & 19.4 & 21 & 29.6 & 0.12 \\
\hline Mononucleosis & 30 & 18.5 & 25 & 13.8 & 0.2 & 8 & 7.4 & 5 & 7.0 & $0.9^{\ddagger}$ \\
\hline STDs that are curable $(n=469)$ & & & & & & & & & & \\
\hline Aids & 40 & 28.0 & 22 & 13.3 & 0.001 & 23 & 24.2 & 16 & 24.6 & 0.9 \\
\hline Syphilis & 33 & 18.2 & 59 & 35.5 & 0.001 & 16 & 16.8 & 28 & 43.1 & $<0.001$ \\
\hline HTLV & 9 & 6.3 & 6 & 3.6 & 0.3 & 5 & 5.3 & 2 & 3.1 & $0.7^{\ddagger}$ \\
\hline HPV & 52 & 36.4 & 37 & 22.3 & 0.006 & 16 & 16.8 & 20 & 30.8 & 0.04 \\
\hline Herpes & 79 & 55.2 & 89 & 53.6 & 0.8 & 34 & 35.8 & 34 & 52.3 & 0.04 \\
\hline Gonorrhea & 50 & 35.0 & 70 & 42.2 & 0.2 & 31 & 32.6 & 32 & 49.2 & 0.04 \\
\hline PID & 13 & 9.1 & 13 & 7.8 & 0.7 & 9 & 9.5 & 3 & 4.6 & $0.4^{\ddagger}$ \\
\hline Trichomoniasis & 3 & 2.1 & 5 & 3.0 & $0.7^{\ddagger}$ & 4 & 4.2 & 3 & 3.1 & $0.9^{\ddagger}$ \\
\hline Chlamydia & 7 & 4.9 & 7 & 4.2 & 0.8 & 2 & 2.1 & 5 & 7.7 & $0.1^{\ddagger}$ \\
\hline Donovanosis & 4 & 2.8 & 2 & 1.2 & $0.4^{\ddagger}$ & 3 & 3.2 & 1 & 1.5 & $0.6^{\ddagger}$ \\
\hline Lymphogranuloma Venereal & 1 & 0.7 & 2 & 1.2 & $0.8^{\ddagger}$ & 5 & 5.3 & 1 & 1.5 & $0.4^{\ddagger}$ \\
\hline Mycoplasma & 3 & 2.1 & 4 & 2.4 & $0.9^{\ddagger}$ & 5 & 5.3 & 1 & 1.5 & $0.4^{\ddagger}$ \\
\hline Urethroma & 2 & 1.4 & 5 & 3.0 & $0.5^{\ddagger}$ & 3 & 3.2 & 2 & 3.1 & $0.9^{\ddagger}$ \\
\hline Chancroid & 6 & 4.2 & 13 & 7.8 & 0.2 & 13 & 13.7 & 7 & 10.8 & $0.6^{\ddagger}$ \\
\hline Viral hepatitis & 13 & 9.1 & 49 & 29.5 & $<0.001$ & 22 & 23.2 & 15 & 23.1 & $0.9^{\ddagger}$ \\
\hline Mononucleosis & 11 & 7.7 & 13 & 7.8 & 0.9 & 5 & 5.3 & 3 & 4.6 & $0.9^{\ddagger}$ \\
\hline
\end{tabular}

* More than one option of answers: sums of the proportions of the categories above $100 \%$; † Chi-square test; $\ddagger$ Fisher's exact test.

Table 2 shows that knowledge regarding STDs that have a cure was adequate for $26.3 \%$ of the girls and $37.1 \%$ of the boys, presenting a statistically significant difference between both genders $(\mathrm{P}=0.02)$. Among the diseases that can are curable (Table 3), herpes stood out with $55.2 \%$ of the girls in the $7^{\text {th }}$ and $8^{\text {th }}$ grades and $53.6 \%$ of high school girls, with no statistical significance $(\mathrm{P}=0.8)$. Among the boys, $35.8 \%$ of those in the $7^{\text {th }}$ and $8^{\text {th }}$ grades and $52.3 \%$ of those in high school reported that herpes had a cure, and this knowledge was statistically significant $(\mathrm{P}=0.04)$. Knowledge about STDs that have a cure also presented significant data among the girls for syphilis $(\mathrm{P}=0.001)$, HPV $(\mathrm{P}=0.006)$, and hepatitis $(\mathrm{P}<0.001)$.
Regarding the forms of infection/transmission presented in Table 2, 38.1\% of the girls and $44.8 \%$ of the boys were aware of correct forms of infection/ transmission. No statistically significant differences were found between the gender $(\mathrm{P}=0.15)$, and $41.4 \%$ of the girls and $51.4 \%$ of the boys knew the proper way to prevent STDs, which was a statistically significant difference $(\mathrm{P}=0.03)$.

Table 4 shows that there was a statistical difference between the school years only for inadequate prevention methods, such as contraceptive pill use for girls $(\mathrm{P}=0.001)$, and non-sharing of objects for girls $(\mathrm{P}=0.003)$ and boys $(\mathrm{P}=0.05)$. 
Table 4 - Variables of adolescents' knowledge regarding forms of infection/transmission and methods to prevent STDs, stratified by gender and school year. Pelotas-RS, Brazil, 2014

\begin{tabular}{|c|c|c|c|c|c|c|c|c|c|c|}
\hline & \multicolumn{5}{|c|}{ Girls } & \multicolumn{5}{|c|}{ Boys } \\
\hline & \multicolumn{2}{|c|}{$\begin{array}{l}7^{\text {th }} \text { and } 8^{\text {th }} \\
\text { grades }\end{array}$} & \multicolumn{3}{|c|}{ High school } & \multicolumn{2}{|c|}{$\begin{array}{l}7^{\text {th }} \text { and } 8^{\text {th }} \\
\text { grades }\end{array}$} & \multicolumn{3}{|c|}{ High school } \\
\hline & $\mathbf{n}$ & $\% *$ & $\mathbf{n}$ & $\% *$ & $\mathbf{P}^{\dagger}$ & $\mathbf{n}$ & $\% *$ & $\mathbf{n}$ & $\% *$ & $\mathbf{P}^{\dagger}$ \\
\hline \multicolumn{11}{|l|}{ Forms of transmission } \\
\hline Vaginal intercourse & 141 & 89.2 & 168 & 93.9 & 0.2 & 90 & 87.4 & 66 & 93.0 & 0.3 \\
\hline Oral sex & 106 & 67.1 & 124 & 69.3 & 0.7 & 69 & 67.0 & 52 & 73.2 & 0.4 \\
\hline Anal sex & 112 & 70.9 & 132 & 73.7 & 0.6 & 74 & 71.8 & 51 & 71.8 & 0.9 \\
\hline Shared Syringes & 119 & 75.3 & 131 & 73.2 & 0.7 & 64 & 62.1 & 51 & 71.8 & 0.2 \\
\hline Piercing & 39 & 24.7 & 58 & 32.4 & 0.15 & 22 & 21.4 & 19 & 26.8 & 0.5 \\
\hline Tattoo & 44 & 27.9 & 66 & 36.9 & 0.07 & 26 & 25.2 & 22 & 31.0 & 0.4 \\
\hline Manicure & 54 & 34.2 & 70 & 39.1 & 0.4 & 28 & 27.2 & 23 & 32.4 & 0.8 \\
\hline Breastfeeding & 30 & 19.0 & 35 & 19.6 & 0.9 & 17 & 16.5 & 12 & 16.9 & 0.9 \\
\hline Blood donation & 61 & 38.6 & 84 & 46.9 & 0.15 & 44 & 42.7 & 30 & 42.3 & 0.9 \\
\hline Blood transfusion & 52 & 32.9 & 68 & 38.0 & 0.3 & 33 & 32.0 & 24 & 33.8 & 0.9 \\
\hline $\begin{array}{l}\text { Sharing of contaminated } \\
\text { objects }\end{array}$ & 39 & 24.7 & 54 & 30.2 & 0.3 & 22 & 21.4 & 14 & 19.7 & 0.8 \\
\hline Using the same toilet & 17 & 10.8 & 23 & 12.9 & 0.6 & 5 & 4.9 & 6 & 8.5 & 0.35 \\
\hline Kissing on the mouth & 35 & 22.2 & 33 & 18.4 & 0.4 & 22 & 21.4 & 12 & 16.9 & 0.6 \\
\hline Hug or handshake & 3 & 1.9 & 8 & 4.5 & 0.2 & 3 & 2.9 & 2 & 2.8 & 0.9 \\
\hline \multicolumn{11}{|c|}{ Methods for STD prevention } \\
\hline Using condoms & 160 & 98.8 & 177 & 98.3 & 0.9 & 103 & 98.1 & 71 & 100.0 & 0.5 \\
\hline Using contraceptive pills & 77 & 47.5 & 50 & 27.8 & $<0.001$ & 39 & 37.1 & 17 & 23.9 & 0.07 \\
\hline Not sharing objects & 36 & 22.2 & 67 & 37.2 & 0.003 & 18 & 17.1 & 21 & 29.6 & 0.05 \\
\hline Not using the same toilet & 10 & 6.2 & 16 & 8.9 & 0.4 & 0 & 0.0 & 7 & 9.9 & $0.001^{\ddagger}$ \\
\hline
\end{tabular}

* More than one option of answers: sums of the proportions of the categories above $100 \%$; † Chi-square test; $\ddagger$ Fisher's exact test.

Table 5 below shows that girls (69.4\%) talked about sexuality with their mothers more than boys (44.5\%). The same statistical significance was found between mothers and fathers $(\mathrm{P}<0.001)$. The school/ teachers presented very low rates of being open to discuss sexuality issues with adolescents, being mentioned only by $7.2 \%$ of girls and $10.3 \%$ of boys, not presenting statistical significance. Nonetheless, school/teachers were reported by $60.4 \%$ of the girls and $54.3 \%$ of the boys as a source of information on STDs, however with no statistical significance between genders. Parents and school stand out as sources of information that adolescents seek to learn about STDs, with statistical significance only for mothers and fathers $(\mathrm{P}=0.01$ and $\mathrm{P}<0.001$, respectively). 
Table 5 - Variables of adolescents' knowledge and sexual behavior related to whom they talk about sex with and what sources of information they seek about STDs. Pelotas-RS, Brazil, 2014.

\begin{tabular}{|c|c|c|c|c|c|}
\hline \multirow{3}{*}{ Variables } & \multicolumn{5}{|c|}{ Gender } \\
\hline & \multicolumn{2}{|c|}{ Female } & \multicolumn{2}{|c|}{ Male } & \multirow[b]{2}{*}{$\mathbf{P}^{\dagger}$} \\
\hline & $\mathbf{n}$ & $\%$ \% & $\mathbf{n}$ & $\%$ * & \\
\hline \multicolumn{6}{|c|}{ With whom they talked about sex $(n=463)$} \\
\hline Mother & 213 & 69,4 & 69 & 44,5 & $<0,001$ \\
\hline Father & 42 & 13,7 & 50 & 32,3 & $<0,001$ \\
\hline Siblings & 45 & 14,7 & 23 & 14,8 & 0,95 \\
\hline Friends & 166 & 54,1 & 85 & 54,8 & 0,9 \\
\hline Boyfriend or girlfriend & 58 & 18,9 & 24 & 15,5 & 0,4 \\
\hline School/teachers & 22 & 7,2 & 16 & 10,3 & 0,25 \\
\hline Health services & 14 & 4,6 & 2 & 1,3 & 0,07 \\
\hline \multicolumn{6}{|c|}{ Who informed them about STDs $(n=516)$} \\
\hline Mother & 238 & 69,8 & 101 & 57,7 & 0,01 \\
\hline Father & 84 & 24,6 & 74 & 42,3 & $<0,001$ \\
\hline Siblings & 36 & 10,6 & 22 & 12,6 & 0,6 \\
\hline Friends & 88 & 25,8 & 37 & 21,1 & 0,2 \\
\hline Boyfriend or girlfriend & 27 & 7,9 & 14 & 8,0 & 0,9 \\
\hline School/teachers & 206 & 60,4 & 95 & 54,3 & 0,2 \\
\hline Health services & 110 & 32,3 & 55 & 33,1 & 0,8 \\
\hline Newspaper/magazine & 130 & 38,1 & 54 & 30,9 & 0,1 \\
\hline
\end{tabular}

\section{DISCUSSION}

About 21 million adolescents live in Brazil, thus there is a need for investment in the educational area in order for these adolescents to acquire knowledge, skills and abilities to develop to their full potential. ${ }^{11}$ In addition, investments in health care, protection and inclusion of these adolescents in the labor market are also essential for developing this segment of the population.

Adolescence is a period when adolescents undergo biopsychosocial modifications, while at the same time they feel the need to have new experiences which can make them vulnerable to STD infections. ${ }^{3,12}$ Exercising sexuality in adolescence continues to be treated by many as an activity of vulnerability due to inadequate protection, often associated with STDs, ${ }^{13}$ and considered as one of the world's public health problems. ${ }^{14}$

The results of this study point out that there are still doubts among participants about the definition of STDs, reiterating the importance of working on this topic, especially considering that some thought that these diseases can be acquired by hand contact, kissing, hugging, sharing objects and using the same toilet as infected people. It was also verified that the adolescents participating in this study were aware of diseases that are considered sexually transmitted, corroborating with data found in another study ${ }^{15}$ which compared knowledge among public and private school students, revealing that $80.1 \%$ and $90.7 \%$, respectively, were had knowledge about STDs.

One study ${ }^{16}$ identified that adolescents had relevant knowledge about STDs. However, they had many doubts and uncertainties at the same time. Educational activities through workshops allow adolescents to clarify their doubts about STDs, as well as help prevent their occurrence. From this perspective, sex education becomes essential in promoting protected sexual relations between adolescents and young people. ${ }^{17-18}$

In this study, condom use was identified as the most effective method for STD prevention. However, the participants referred to contraceptive use as a preventive method. These data confirm the findings 
of other studies, ${ }^{4,15}$ in which the male condom was cited by $71.1 \%$ of the participants as a method, and adolescents from both public and private schools demonstrated unsatisfactory knowledge about contraceptive methods.

It should be emphasized that information alone is not sufficient to promote the adoption of preventive behaviors, and it is also important to promote reflection and awareness among adolescents about these issues. In this way, behavior changes can be encouraged, respecting the individuality of each one as to the capacity to receive and process the information to use it properly. ${ }^{19}$

Hormonal, emotional and social changes occur at around nine to ten years of age, instigating the rediscovery of the body as a source of pleasure, with manifestations of interest appearing, affection and desire for people outside the family environment. ${ }^{20}$ Such interest may stimulate the onset of sexual activity.

In this context, it should be noted that the onset of sexual activities occurred between 14 and 16 years for the participants of this study and condom use was greater for the girls. It is emphasized that when adolescents initiate sexual activities early, they may be vulnerable to STD infection. ${ }^{19,21}$ This finding has already been confirmed in another study, ${ }^{6}$ which also reported that early sexual initiation may lead to a 1.7 fold increase in infection by an STD.

Another study ${ }^{19}$ reported that first sexual intercourse was precocious for $18.7 \%$ of participants between 12 and 13 years of age, of whom $64.3 \%$ used a condom; however, only $42.9 \%$ continued to use it in later relations. Thus, these data are in agreement with the findings of this study and another study ${ }^{18}$ in which the girls reported greater use of condoms.

It should be noted that most of the study participants had little knowledge about sexually transmitted diseases and were unaware of their forms of infection/transmission, corroborating a study $^{22}$ conducted with Early Childhood and Primary Education students in Spain where there was greater knowledge among participants about HIV, while other diseases were less mentioned. In this study, responses considered as correct by participants were chancroid, chlamydia, gonorrhea, pelvic inflammatory disease, donovanosis, viral hepatitis, venereal lymphogranuloma, syphilis, trichomoniasis, infections caused by the human papilloma virus and by the Human T-lymphotropic virus, as well as genital herpes and HIV. ${ }^{14}$ Regarding the form of infection/transmission, the expected responses were related to sexual intercourse with an infected person without the use of condoms, sharing syringes and needles, reusing sharp objects contaminated with blood or fluids, blood transfusion and an infected mother transmitting the disease to the child during pregnancy, delivery or breastfeeding. ${ }^{14}$

Forms considered inadequate for infection/ transmission reported by adolescents included the act of giving blood, shaking hands, hugging, sharing objects, and using the same toilet as sources of infection. According to Ordinance 2.712 of 2013 of the Ministry of Health ${ }^{23}$ governing blood donation, there is no risk of infection occurring during the act of donating, since all the material used for the donation process is exclusive to the donor. The possibility of STD infection was not found in the consulted literature regarding hugs, handshakes, sharing objects or using the toilet.

The present study found that adolescents sought information from reliable sources such as parents, siblings, teachers, and health services. However, it should be noted that seeking parents for information occurred for about half of the adolescents, which is a relevant fact considering that nowadays parents have little time to dedicate themselves to their children, often transferring this responsibility to the school. ${ }^{13,17-18}$

It is worth noting that other sources are not always well prepared to provide adequate guidance. Schools can be a place for the development of sex education because adolescents spend most of their time in it and also because it is a space for socialization, training and information. Given these aspects, schools should be considered as an extension of health services in order to promote a commitment to adolescents' own sexuality. ${ }^{24}$

In addition to increasing health as a preventive policy, education is a protective factor. Public policy aimed at adolescents lies in formal education, as one study ${ }^{25}$ indicates that sexual activity and consequently STD infections tend to decrease with increasing levels of schooling, as well as having good relationships with their parents reduces the chances of adolescents getting involved in sexual relations. ${ }^{26}$ Thus, encouraging adolescents and young people to dialogue with their parents and an increase in education in the country for them to qualify family relationships and pursue education beyond basic education may have immediate effects on the sexual and reproductive health of the population.

We believe in the need to encourage school adherence to the program proposed by the Ministry of Health ${ }^{9}$ on sexual and reproductive education for students in the final years of middle school and 
high school, thereby sharing knowledge among adolescents so that they can protect themselves from STDs once they start being sexually active. However, for this reality to happen, qualifying teachers is fundamental. One study ${ }^{27}$ analyzing the schools' posture and teachers' attitudes towards sex education indicated that they recognize the importance of the theme, however most do not have sufficient knowledge to promote sexual orientation to adolescents, focusing more on the biological aspects of sexuality than on the feelings and values involved.

Continued specific training on sexuality education through deepening knowledge gives teachers competence and security to approach the subject with adolescents. Nonetheless, the work performed by the school does not replace or compete with the family's role and should only complement it. ${ }^{24}$ Fundamentally, it is necessary that the debate on STDs promote access to adequate information, favoring a change of attitude towards sexual practice.

It is important to promote spaces for discussion about this theme in the school context through workshops on sex education by health professionals, since it can provide positive results regarding behavioral changes among adolescents. ${ }^{28-29}$ Corroborating studies emphasize the need for the participation of health professionals ${ }^{20}$ articulated with the school and with the family, ${ }^{30}$ providing conversations groups, lectures and reflections that contemplate the themes of sexuality and reproductive health in the school environment.

Thus, in view of the growing picture of new cases of STDs among the population, and especially among adolescents, it is very important to know the realities in order to generate discussions on the subject. This study corroborates that the main prevention strategy in adolescence is addressing the problem of STDs and establishing intervention mechanisms that provide adolescents with being able to recognize the risks that permeate unsafe sexual practice. $^{31}$

\section{CONCLUSION}

Among the results found in this study, 89.2\% of the girls and $90.3 \%$ of the boys knew how to properly define the STD concept, and $78.0 \%$ of the girls and $89.3 \%$ of the boys had knowledge about the diseases. Most STDs reported by adolescents were Acquired Immunodeficiency Syndrome (AIDS), herpes, gonorrhea, HPV, syphilis and viral hepatitis. Knowledge about the STDs that have cure was adequate for $26.3 \%$ of the girls and $37.1 \%$ of the boys.
Regarding forms of infection/transmission, $38.1 \%$ of the girls and $44.8 \%$ of the boys knew them; $69.4 \%$ of the girls and $44.5 \%$ of the boys talked about sexuality with their mother, and the school was referred by $60.4 \%$ of the girls and $54.3 \%$ of the boys as a source of information. For $98.5 \%$ of the girls and $98.9 \%$ of the boys, condom use was the most effective method for STD prevention; however, $37.1 \%$ of the girls and $30.5 \%$ of the boys reported contraceptive use as a preventive method.

Based on the results found in this study, it is possible to highlight the importance of promoting adolescent health through information and school activities that also include families, as well as the union between health services and teachers with the aim to empower these adolescents in regards to decisions on safe sexual practices.

Considering that early initiation of sexual activities may lead to greater vulnerability to sexually transmitted diseases, it is considered necessary to develop educational strategies to minimize negative health outcomes. To this end, knowledge about STDs should be encouraged and shared among adolescents, and campaigns to prevent STDs should be conducted to promote health.

We are aware that this study may present weaknesses, since these data were collected in only one school and it we did not intend to generalize the results. However, it should be emphasized that the educational institution scenario of this study is a public school that welcomes students from various social classes.

\section{REFERENCES}

1. Camargo BV, Botelho LJ. Aids, sexualidade e atitudes de adolescentes sobre proteção contra o HIV. Rev Saúde Pública [Internet]. 2007 [cited 2014 Out 13]; 41(1):61-8. Available from:http://www.scielo.br/ pdf/rsp/v41n1/5296.pdf

2. Moreira TMM, Viana DS, Queirz MVO, Jorge MSB. Conflitos vivenciados pelas adolescentes com a descoberta da gravidez. Rev Esc Enferm USP [Internet]. 2008 [cited 2014 Out 13]; 42(2):312-20. Available from: http://www.scielo.br/pdf/reeusp/ v42n2/a14.pdf

3. Nery IS, Mendonça RCM, Gomes IS, Fernandes ACN, Oliveira DC. Reincidência da gravidez em adolescentes de Teresina, PI, Brasil. Rev Bras Enferm [Internet]. 2011 [cited 2014 Out 13]; 64(1):31-7. Available from: http://www.scielo.br/pdf/reben/ v64n1/v64n1a05.pdf

4. Doreto DT, Vieira EM. O conhecimento sobre doenças sexualmente transmissíveis entre adolescentes de baixa renda em Ribeirão Preto, São Paulo, Brasil. Cad 
Saúde Pública [Internet]. 2007 [cited 2014 Out 13]; 23(10):2511-6. Available from: http://www.scielo. $\mathrm{br} / \mathrm{pdf} / \mathrm{csp} / \mathrm{v} 23 \mathrm{n} 10 / 26 . \mathrm{pdf}$

5. Moreira SB, Pereira PS, Brito AED, Barros LM. DSTs: percepção dos estudantes da Escola São Vicente de Paula, EXU-PE. Enciclopédia Biosfera, Centro Científico Conhecer [Internet]. 2012 [cited 2014 Out 15]; 8(15):2078-88. Available from: http://www. conhecer.org.br/enciclop/2012b/ciencias \% 20 humanas/dsts.pdf

6. Carret MLV, Fassa AG, Silveria DS, Bertoldi AD, Hallal P. Sintomas de doenças sexualmente transmissíveis em adultos: prevalência e fatores de risco. Rev Saúde Pública [Internet]. 2004 [cited 2014 Out 15]; 38(1):7684. Available from: http://www.scielo.br/pdf/rsp/ v38n1/18455.pdf

7. Cordeiro LP, Silva NSR, Barbosa SP. Conhecimento e comportamento sobre DST/aids entre acadêmicos de enfermagem do Centro Universitário do Leste de Minas Gerais. Rev. Enfermagem Integrada Ipatinga: Unileste-MG [Internet]. 2009 [cited 2014 Out 17]; 2(1):126-38. Available from: http:/ / www. unilestemg.br/enfermagemintegrada/artigo/ v2/Larissa_cordeira_Nayara_silva_e_Simone_ barbosa.pdf

8. Kirby D. The impact of schools and school programs upon adolescent sexual behavior. J Sex Res. 2002; 39(1):27-33.

9. Ministério da Saúde (BR). Guia de sugestões de atividades semana saúde na escola. Sexualidade e saúde reprodutiva. Brasília (DF): MS; 2013.

10. Ministério da Saúde (BR). Secretaria de Vigilância em Saúde. Programa Nacional de DST e AIDS. Pesquisa de Conhecimento, Atitudes e Práticas na População Brasileira de 15 a 54 anos, 2004. Brasília (DF): MS; 2005.

11. United Nations Children's Fund (UNICEF). Situação Mundial da Infância 2011. New York: UNICEF; 2011.

12. Toledo MM, Takahashi RF, Guanilo MC. Elementos de vulnerabilidade individual de adolescentes ao HIV/ aids. Rev Bras Enferm [Internet]. 2011 [cited 2014 Out 18]; 64: 370-5. Available from: http:/ /www.scielo.br/ pdf/reben/v64n2/a24v64n2.pdf

13. Brandão ER. Desafios da contracepção juvenil: interseções entre gênero, sexualidade e saúde. Ciênc Saúde Coletiva [Internet]. 2009 [cited 2014 Out 19]; 14(4):1063-71. Available from: http://www.scielo. $\mathrm{br} / \mathrm{pdf} / \mathrm{csc} / \mathrm{v} 14 \mathrm{n} 4 / \mathrm{a} 08 \mathrm{v} 14 \mathrm{n} 4 . \mathrm{pdf}$

14. Ministério da saúde (BR). Coordenação Nacional de DST e AIDS. Secretaria de Vigilância em Saúde. Doenças sexualmente transmissíveis. Manual de controle das doenças sexualmente transmissíveis. Brasília (DF): MS; 2005.

15. Martins LBM, Costa Paiva LH, Osis MJD, Sousa MH, Neto AMP, Tadini V. Fatores associados ao uso de preservativo masculino e ao conhecimento sobre DST/aids em adolescentes de escolas públicas e privadas do município de São Paulo, Brasil. Cad Saúde
Pública [Internet]. 2006 [cited 2014 Out 22]; 22(2):31523. Available from: http:/ / www.scielo.br/pdf/csp/ v22n2/09.pdf

16. Freitas CASL, Frota AOQM, Rios AJS, Vasconcelos MN, Goyanna NF, Ximenes Neto FRG. Prevenção às doenças sexualmente transmissíveis: educação em saúde com grupo de adolescentes do ensino médio. Rev Soc Bras Enferm Ped [Internet]. 2013 [cited 2014 Out 22]; 13(2):105-13. Available from: http://www. sobep.org.br/revista/component/zine/article/173preveno-s-doenas-sexualmente-transmissveiseducao-em-sade-com-grupo-de-adolescentes-doensino-mdio.html

17. Heilborn ML, Aquino EM, Bozon M, Knauth DR, organizadores. O aprendizado da sexualidade: reprodução e trajetórias sociais de jovens brasileiros. Rio de Janeiro: Garamond, 2006.

18. Brêtas JRS, Ohara CVS, Jardim DP, Junior WA, Oliveira JR. Aspectos da sexualidade na adolescência. Ciênc Saúde Coletiva [Internet]. 2011 [cited 2014 Out 23]; 16(7):3221-8. Available from: http:/ / www.scielo. $\mathrm{br} / \mathrm{pdf} / \mathrm{csc} / \mathrm{v} 16 \mathrm{n} 7 / 21 . \mathrm{pdf}$

19. Madureira L, Marques IR, Jardim DP. Contracepção na adolescência: conhecimento e uso. Cogitare Enferm [Internet]. 2010 [cited 2014 Out 23]; 15(1):100-5. Available from http://ojs.c3sl.ufpr.br/ojs/index. $\mathrm{php} /$ cogitare/article/view/17179/11314

20. Tilahun M, Mengistie B, Egata G, Reda AA . Health workers' attitudes toward sexual and reproductive health services for unmarried adolescents in Ethiopia. Reprod Health. 2012; 9:19.

21. Dessunti EM, Reis AOA. Fatores psicossociais e comportamentais associados ao risco de DST/aids entre estudantes da área de saúde. Rev Latino-am Enfermagem [Internet]. 2007 [cited 2014 Out 24]; 15(2). Available from: http://www.scielo.br/pdf/rlae/ v15n2/pt_v15n2a12.pdf

22. RodríguezMM, MuñozCR,SánchezMI. Conocimientos y actitudes sobre sexualidad en adolescentes de primer Curso de grado en educación infantil y primaria de la Universidad de Jaén. Enferm Glob [Internet]. 2016 Ene [cited 2016 Abr 20];15(41):164-73. Available from: http://scielo.isciii.es/pdf/eg/v15n41/docencia4.pdf

23. Ministério da Saúde (BR). Portaria MS 2712 de 12 de novembro de 2013. Redefine o regulamento técnico de procedimentos hemoterápicos. Brasília (DF): MS; 2013.

24. Dias SCG. Educação sexual nas escolas do Concelho de Oeiras: Percepção de professores e alunos [dissertação na internet]. Lisboa (PT): Universidade Técnica de Lisboa. Faculdade de Motricidade Humana/ Programa de Pós-Graduação em Ciências da Educação na Especialidade de Educação para a Saúde; 2013 [cited 2014 Out 28]. Available from: https://www. repository.utl.pt/ bitstream/10400.5/5823/1/ ED $\% 20$ SEXUAL $\% 20$ NAS\%20ESCOLAS $\% 20$ DO $\% 20$ CONCELHO\%20DE\%20OEIRAS.pdf 
25. Berlofi LM, Alkmin ELC, Barbieri M, Guazzelli CAF, Araújo, FF. Prevenção da reincidência de gravidez em adolescentes: efeitos de um programa de planejamento familiar. Acta Paul Enferm [Internet]. 2006 [cited 2014 Out 30]; 19(2):196-200. Available from: http:/ / www. scielo.br/pdf/ape/v19n2/a11v19n2.pdf

26. Habel MA, Dittus PJ, Rosa CJ, Chung EQ, Kerndt PR. Daily participation in sports and students' sexual activity. Perspect Sex Reprod Health. 2010 Dec; 42(4):244-50.

27. Jardim DP, Brêtas JRS. Orientação sexual na escola: a concepção dos professores de Jandira-SP. Rev Bras Enferm [Internet]. 2006 [cited 2014 Out 24]; 59(2):15762. Available from: http://www.scielo.br/pdf/ reben/v59n2/a07.pdf

28. Baccarat GMC, Almeida FM, Alencastro LC, Fonseca MK, Pires SSS. Sexualidade na adolescência: mitos e tabus. Cienc Enferm [Internet]. 2012 [cited 2016 Abr 18]; 18(3):25-37. Available from: http:/ / www.scielo. cl/pdf/cienf/v18n3/art_04.pdf

29. Villegas-Castaño A, Tamayo-Acevedo LS. Prevalencia de infecciones de transmisión sexual y factores de riesgo para la salud sexual de adolescentes escolarizados, Medellín, Colombia, 2013. Iatreia [Internet]. 2016 [cited 2016 Abr 20]; 29(1):5-17. Available from: http:/ / www.scielo.org.co/pdf/iat/ v29n1/v29n1a01.pdf

30. Deptula DP, Henry DB, Schoeny ME. How can parents make a difference? Longitudinal associations with adolescent sexual behavior. J Fam Psychol. 2010 [cited 2016 Abr 13]; 24(6):731-9. Available from: http:// dx.doi.org/10.1037/a0021760

31. Silva IR, Sousa FGM, Silva MM, Silva TP, Leite JL. Complex thinking supporting care strategies for the prevention of DSTs/aids in adolescence. Texto Contexto Enferm [Internet]. 2015 [cited 2015 Out 17]; 24(3):859-66. Available from: http:/ / www.scielo.br/ pdf/tce/v24n3/0104-0707-tce-24-03-00859.pdf 